\title{
MODEL DOKUMENTASI KEPERAWATAN
}

\author{
FLORENCE ANGELINE NAINGGOLAN
}

Florenceangeline123@gmail.com

\section{Latar Belakang}

Dokumentasi merupakan catatan otentik dalam penerapan manajemen asuhan keperawatan profesional. Perawat profesional diharapkan dapat menghadapi tuntutan tanggung jawab dan tanggung gugat terhadap segala tindakan yang dilaksanakan. Hal ini didukung oleh Kozier (2005),

Pendokumentasian merupakan bukti akuntabilitas tindakan keperawatan yang dilakukan perawat dalam pelayanan keperawatannya terhadap pasien.

Dokumentasi keperawatan merupakan bukti pencatatan dan pelaporan yang dimiliki perawat dalam melakukan catatan keperawatan yang berguna untuk kepentingan klien, perawat dan tim kesehatan dalam memberikan pelayanan kesehatan.

Komponen penting dalam pendokumentasian adalah komunikasi, proses keperawatan dan standar asuhan keperawatan. Efektifitas dan efisiensi sangat bermanfaat dalam mengumpulkan informasi yang relevan serta akan meningkatkan kualitas dokumentasi keperawatan.

Proses profesionalisme bidang keperawatan adalah suatu proses agar di peroleh hasil asuhan keperawatan yang bermutu, efektif, dan efisien sesuai dengan kebutuhan agar pelaksanaan nya di lakukan secara sistematis, dinamis, dan berkelanjutan.

Proses ini merupakan proses pengakuan terhadap sesuatu yang dirasakan, dinilai dan diterima secara spontan oleh masyarakat.Proses keperawatan terdiri dari lima tahap yang sequensial dan berhubungan. Antara lain yaitu pengkajian, diagnosis, perencanaan, pelaksanaan, dan evaluasi. Tahap tersebut berintegrasi dalam mendefinisikan suatu tindakan perawatan. Salah satunya adalah implementasi atau pe laksanaan. Proses keperawatan menyediakan struktur bagian praktis dengan penggunaan pengetahuan dan keterampilan yang dilakukan oleh perawat untuk mengekspresikan kebutuhan perawatan ( human caring ). 
Dalam memberikan asuhan keperawatan yang profesional diperlukan sebuah pendekatan manajemen yang memungkinkan diterapkannya metode penugasan yang dapat mendukung penerapan perawatan yang profesional di rumah sakit.Sebagai profesi, keperawatan dituntut untuk memiliki kemampuan intelektual, interpersonal kemampuan teknis dan moral.

\section{Metode}

Setiap organisasi mempunyai metode tersendiri atau format standar untuk dokumentasi keperawatan dalam catatan khusus.Pencatatan telah di pandang sebagai riwayat sekunder untuk perawatatan pasien. Sistem pendokumentasian yang digunakan harus mengomunikasikan status pasien, pemberian perawatan spesifik, dan respons pasien terhadap perawatan. Metode kualitatif digunakan dengan mengumpulkan data untuk di analisis yang berfokus pada model dalam asuhan keperawatan.

\section{Hasil}

Proses keperawatan mengandung unsur-unsur yang bermanfaat bagi perawat dan klien. Perawat dan klien membutuhkan proses asuhan keperawatan, merencanakan, melaksanakan, dan menilai hasil dari asuhan keperawatan. Semua itu memerlukan pendokumentasian sehingga perawat mendapatkan data klien dengan sistematis.

Dokumentasi merupakan salah satu sarana komunikasi antar petugas kesehatan dalam rangka pemulihan kesehatan klien.

Perawat bertanggung jawab dan bertanggung gugat dalam pencatatan tindakan keperawatan. Tanpa dokumentasi yang benar dan jelas, kegiatan pelayanan keperawatan yang telah dilaksanakan oleh seorang perawat tidak dapat dipertanggungjawabkan dalam upaya peningkatan mutu pelayanan keperawatan dan perbaikan status kesehatan klien.

Menurut Brian Gugerty, et all dalam Challenges and Opportunities in Documentation of the Nursing Care of Patients Report of the Maryland Nursing Documentation Work Group (2007), perawat setiap harinya dalam melakukan rutinitas menghabiskan 15-25\% waktunya digunakan untuk mendokumentasikan asuhan keperawatan. Tetapi perawat menganggap bahwa dokumentasi tidak penting atau berlebih-lebihan, sehingga sebagian besarwaktunya dipakai untuk melakukan tindakan keperawatan secara langsung kepada pasien.Handayaningsih (2007) menyebutkan bahwa standart dokumentasi menjadi hal yang penting dalam setiap tindakan keperawatan, namun hal ini kadang tidak disadari oleh perawat.

Dokumentasi keperawatan adalah suatu catatan yang memuat seluruh data yang dibutuhkan untuk menentukan diagnosis keperawatan, perencanaan keperawatan, tindakan keperawatan, dan 
penilaian keperawatan yang disusun secara sistematis, valid, dan dapat dipertanggungjawabkan secara moral dan hukum (Zaidin Ali,2009).

Dokumentasi keperawatan tidak hanya sebagai persyaratan untuk akreditasi, tetapi juga merupakan catatan permanen tentang apa yang terjadi pada klien.

Standar dokumentasi adalah suatu pernyataan tentang kualitas dan kuantitas dokumentasi yang dipertimbangkan secara adekuat dalam suatu situasi tertentu, sehingga memberikan informasi bahwa adanya suatu ukuran terhadap kualitas dokumentasi keperawatan.

\section{Pembahasan}

Model pemberian asuhan keperawatan perlu disesuaikan dengan kondisi dan kebutuhan pasien yang sampai saat ini terdiri dari enam model yang meliputi: SOR (Source-Oriented Record), POR (Problem Oriented Record), Progress Notes, CBE (Charting By Exception), PIE (Problems Intervention and Evaluation), Focus (Process Oriented System), (Marquis \& Huston, 2012; Blais, Hayes, Kozier, \& Erb, 2007; Tomey, 2009).

Masing-masing model pemberian asuhan keperawatan mempunyai keuntungan dan kerugiannya.

Pendokumentasian keperawatan menggunakan model POR mempunyai keuntungan yang dikemukakan oleh Damayanti (2010), bahwa penggunaan model POR mempunyai metode logis untuk melakukan analisis dan pemecahan masalah, memungkinkan komunikasi yang lebih efektif, terdiri atas pembahasan singkat tentang setiap masalah yang ada dalam daftar masalah dan bagaimana masalah tersebut berakhir, apakah berhasil atau tidak berhasil diselesaikan. Model Pendokumentasian keperawatan menggunakan model problem oriented record (POR) lebih mudah diterapkan karena model ini memusatkan data tentang klien dan didokumentasikan dan disusun menurut masalah klien.

Sistem dokumentasi jenis ini mengintegrasikan semua data mengenai masalah yang dikumpulkan oleh dokter, perawat atau tenaga kesehatan lain yang terlibat dalam pemberian layanan kepada klien.

Model pendokumentasian dalam asuhan keperawatan, antara lain:

\section{SOR (Source Oriented record)}

Model ini merupakan model dokumentasi yang berorientasi pada sumber informasi. Model SOR menempatkan catatan atas dasar disiplin orang atau sumber yang mengelola pencatatan. Bagian penerimaan klien mempunyai lembar isian tersendiri, lembaran riwayat penyakit dan perkembangan penyakit, perawat menggunakan catatan keperawatan.

Keuntungan :

1.Menyajikan data yang secara berurutan dan mudah diidentifikasi

2.Memudahkan perawat untuk secara bebas bagaimana informasi akan dicatat 
Kerugian :

1.Potensial terjadinya pengumpulan data yang terfragmentasi karena tidak berdasarkan urutan waktu.

2.Superficial pencatatan tanpa data yang jelas.

3.Memerlukan pengkajian data dari beberapa sumber untuk menentukan masalah dan tindakan kepada klien.

\section{POR (Problem - Oriented Record)}

Model Pendokumentasian keperawatan menggunakan model problem oriented record (POR) lebih mudah diterapkan karena model ini memusatkan data tentang klien dan didokumentasikan dan disusun menurut masalah klien. Sistem dokumentasi jenis ini mengintegrasikan semua data mengenai masalah yang dikumpulkan oleh dokter, perawat atau tenaga kesehatan lain yang terlibat dalam pemberian layanan kepada klien.

Pendokumentasian keperawatan menggunakan model POR mempunyai keuntungan yang dikemukakan oleh Damayanti (2010), bahwa penggunaan model POR mempunyai metode logis untuk melakukan analisis dan pemecahan masalah, memungkinkan komunikasi yang lebih efektif, terdiri atas pembahasan singkat tentang setiap masalah yang ada dalam daftar masalah dan bagaimana masalah tersebut berakhir, apakah berhasil atau tidak berhasil diselesaikan.

Model Pendokumentasian keperawatan menggunakan model problem oriented record (POR) lebih mudah diterapkan karena model ini memusatkan data tentang klien dan didokumentasikan dan disusun menurut masalah klien. Sistem dokumentasi jenis ini mengintegrasikan semua data mengenai masalah yang dikumpulkan oleh dokter, perawat atau tenaga kesehatan lain yang terlibat dalam pemberian layanan kepada klien.

\section{PROGRESS NOTES}

Model dokumentasi yang berorientasi pada perkembangan dan kemajuan klien, jenis catatan yang dapat digunakan dalam progress notes yaitu: Catatan perawatan biasanya di tulis tiap 24 jam, Catatan pemulangan dan ringkasan rujukan.

\section{CBE (Charting By Exeption)}

CBE adalah sistem dokumentasi yang hanya mencatat secara naratif hasil atau penemuan yang menyimpang dari keadaan normal atau standar.

Keuntungan CBE yaitu mengurangi penggunaan waktu untuk mencatatsehingga lebih banyak waktu untuk asuhan langsung pada klien, lebih menekankan pada data yang penting saja, mudah untuk mencari data yang penting, pencatatan langsung ketika memberikan asuhan, pengkajian 
yang terstandar, meningkatkan komunikasi antara tenaga kesehatan, lebih mudah melacak respons klien

\section{PIE (Problem intervention \& Evaluation )}

PIE adalah suatu singkatan dari ( Identifikasi Problem, Intervenstion danEvaluation ). Sistem pencatatan adalah suatu pendekatan orientasi - proses pada dokumentasi dengan penekanan pada proses keperawatan dan diagnose keperawatan.

Dimulai dari pengkajian ketika pertama kali klien masuk ke Rumah sakit, diikuti dengan pelaksanaan pengkajian sistem tubuh pada setiap pergantian dinas, Data masalah dipergunakan untuk asuhan keperawatan dalam waktu yang lama dan juga untuk masalah yang kronis,Intervensi yang dilaksanakan dan rutin, didokumentasi dalam flow sheet, Catatan perkembangan digunakan untuk intervensi yang spesifik, Masalah yang ditemukan pada klien,

\section{Focus ( Process Oriented System )}

Pencatatan Focus adalah suatu proses orientasi dan klien fokus. Hal inidigunakan proses keperawatan untuk mengorganisir dokumentasi asuhan. Menuliskan catatan perkembangan, format DAR ( Data Action Response ) :

Data : Berisi tentang data subyektif dean obyektif yangmengandung dokumentasi fokus. Action : Merupakan tindakan keperawatan yang segera atauyang akan dilakukan berdasarkan pengkajian / evaluasi keadaan klien.

Response : Menyediakan keadaan respon klien terhadap tindakan medis atau perawat

\section{Penutup}

Dokumentasi keperawatan adalah suatu catatn yang memuat seluruh informasi yang dibutuhkan untuk menentukan diagnosis keperawatan.

Asuhan keperawatan berkaitan erat dengan dokumentasi keperawatan. Dalam pendokumentasian keperawatan terdiri dari enam macam model, yaitu:

1. Model dokumentasi SOR (Source - Oriented Record),

2.Model dokumentasi POR (Problem - Oriented Record),

3.Model dokumentasi Progress Notes, 
4.Model dokumentasi CBE (Charting By Exception),

5.Model dokumentasi PIE (Problems Intervention \& Evaluation),

6.Model dokumentasi Focus.

\section{Referensi}

Aziz, Alimul. Pengantar Dokumentasi Proses Keperawatan. Jakarta: EGC.2009

Dinarti, A. . Dokumentasi Keperawatan. Jakarta: Trans Info Media

Handayaningsi. 2012. Dokumentasi Keperawatan. Yogjakarta : Mitra CendikiaPress.

Hutahaen, Serii. Konsep dan Dokumentasi ProsesKeperawatan. Jakarta: Info Media Jakarta

Iyer, Patricia W., \& Camp, Nancy H. 2015.Dokumentasi keperawatan: suatu pendekatan proses keperawatan. Edisi III.Jakarta: Penerbit EGC.

Serri, H. (2010). Konsep dan Dokumentasi Proses Keperawatan. Jakarta: Trans Info Medika

Sitorus, Ratna. Model PraktikKeperawatanProfesional diRumahSakit.Jakarta : EGC

Simamora, R. (2009). Dokumentasi Proses Keperawatan.

Simamora, R. H., Purba, J. M., Bukit, E. K., \& Nurbaiti, N. (2019). Penguatan Peran Perawat Dalam Pelaksanaan Asuhan Keperawatan Melalui Pelatihan Layanan Prima. JPPM (Jurnal Pengabdian Dan Pemberdayaan Masyarakat), 3(1), 25-3

Sugiyati, Sri. 2015. Hubungan Pengetahuan Perawat Dalam Dokumentasi Keperawatan Dsengan Pelaksananya Di Rawat Inap RSI Kendal. Kendal : Vol. 8 No. 2 Oktober 2015 : 109 - 125

Supratti, S., \& Ashriady, A. (2018).Pendokumentasian Standar Asuhan Keperawatan Di Rumah Sakit Umum Daerah Mamuju. Jurnal Kesehatan Manarang,2(1), 44-51.

Nursalam, 2008, Proses dan Dokumentasi Keperawatan : Konsep danPraktik, SalembaMedika, Jakarta. 